\title{
Peculiarities of Russia's Geopolitical Status in the Middle East
}

\author{
Ruslan Shangaraev \\ Dept. of Public Administration in Foreign Policy Activity \\ Diplomatic Academy of the Ministry of Foreign Affairs of \\ the Russian Federation \\ Moscow, Russia \\ shang143@mail.ru
}

\author{
Olga Timakova \\ Dept. of Political Theory and Political Philosophy \\ Diplomatic Academy of the Ministry of Foreign Affairs of \\ the Russian Federation \\ Moscow, Russia \\ olga.timakova12@gmail.com
}

\begin{abstract}
When realizing its interests, Moscow acts in the Middle East quite flexibly. Giving priority to its own strategic goals on the international arena and pursuing a pragmatic foreign policy Russia tries to earn a reputation among the countries of the Middle East region as a strong, non-ideological and reliable political power.

The purpose of the study is to determine the priorities of Russia's foreign policy in the Middle East, systematize the goals and objectives of Russian foreign policy and assess the role of Russia as an important external player in one of the most unstable and at the same time strategically important and promising regions.

Methods and the results of the study. In the course of the study, the comparative analysis was used, allowing to construct the system of Russia's involvement in political processes in the Middle East while defining Moscow's role in the recent developments.

Conclusion and recommendations. Recently, it is possible to observe a number of Russian actions based on foreign policy balancing, in particular, the cessation of arms supplies to Iran, as well as the limitation of arms exports to Syria in order to maintain good relations with Israel. In a similar vein, Russia acts by balancing in economic and political spheres.
\end{abstract}

Keywords: Middle East, Russia, Turkey, Iran, Syria, Qatar, ISIS, strategic interests, national security, regional stability

\section{INTRODUCTION}

With respect to the hierarchy of the modern Russia's foreign policy priorities, that are enshrined in the major foreign policy documents, the Middle East had traditionally occupied a place right after the USA, Europe, China and the leading Asian states $[1 ; 2]$. At the same time, the contemporary foreign policy logic of Russia seeks to achieve the country's lost status and ambitions in the international arena. That had repeatedly been confirmed by the political leadership [3]
Thus, assessing the role of the country in the international arena as part of his speech at the 2016 Valdai Forum, Vladimir Putin emphasized: "There are many countries that, like Russia, can rely on a thousand-year history, and we have learned to value our identity, freedom and independence. At the same time, we are not striving either for global dominance, nor for any expansion, nor for confrontation with anyone" [4]. In a similar spirit, the president's statement on the contemporary world leadership was reflected in the article "Time to trust Russia, a common front against terror," published by the Italian newspaper "La Stampa": "In our understanding, real leadership today does not consist in inventing illusory threats and, while speculating on them, try to take over, but in seeing real problems, and assisting to unite the efforts of the states in resolving them. And that is how Russia today understands its role in world affairs" [5].

\section{METHODS}

Consequently taking into account the current foreign policy context, Russia is resorting to the search for new potential opportunities in the international arena, which means the necessity to include the Middle East in the country's sphere of strategic interests [6, 14].

The point of view of the Director of the Carnegie Moscow Center, Dmitry Trenin seemed noteworthy - according to him the Soviet Union's refusal of a military and political presence in the Middle East region at the beginning of hostilities in the Persian Gulf in many ways cost it the loss of key positions in the international arena. In that sense, the return of Russia to the international arena as one of the leading world states is logically accompanied by the intensification of foreign policy activity in the Middle East, which is seen by Moscow as a kind of regional test site [7]. A hypothetical plus for the international image of Russia in this case would be the ability to consolidate the role of an important external actor in one of the most unstable and at the same time strategically important and promising regions. 
Involving Washington on a par with Moscow as a guarantor of a ceasefire agreement;

The creation of a broad coalition that unites regional and external forces to combat ISIS [10].

\section{RESULTS}

It should be noted that Moscow quite successfully began to implement the plan. Contrary to skepticism about the possibility of a repeat of the Afghan campaign, the Russian Aerospace Forces and the Navy demonstrated the effectiveness with minimal losses. Thus, Russia managed not to "get bogged down" in Syria, being drawn into the traditional confrontation between Shi'a and Sunnis [11]. On the contrary, having strengthened relations with the Kurds, Russia continued to develop dialogue with Qatar and Saudi Arabia, while actively trying to attract Egypt to its side.

At the same time, in this situation the main risk for Moscow is the limited resources for campaigning in connection with the difficult economic situation in Russia. On the one hand, technically, the cost of the Syrian campaign for Russia is comparable to the cost of large, full-scale military exercises [12]. Moreover, Russia is making efforts to achieve the contracts for the export of arms and other goods in parallel with diplomatic support from the governments of Iran, Egypt and Iraq.

On the other hand, the undertaken foreign policy obligations entail additional costs. In such circumstances, it is very important for Moscow to avoid possible geopolitical accidents in the region. Nevertheless, as practice has shown, Russia failed to avoid it - the most significant of them led to a sharp aggravation of the Russian-Turkish relations. As Dmitry Trenin notes, the accident between Russia and Turkey is of a special nature.

Turkey actions to shot down the Russian SU-24 fighter are classified differently. Russia reacted as severely as possible to this incident, metaphorically described it as a "stab in the back" and aggression against Russia. In turn, Ankara reacted to the situation no less harshly, openly demonstrating its own ambitions to dictate the rules of the game in the region without any regard to traditional world powers $[13,55]$. A similar line was enshrined in Turkey's foreign policy documents in 2016, where Russia is represented as a state that intervenes in the affairs of other countries without taking their opinions into account and is guided exclusively by its own geopolitical ambitions.

The Russian response that followed in the form of a series of sanctions against Turkey made it clear that Moscow did not intend to leave the situation and would actively draw red lines in relations with Ankara. As a result, the relations were in the lowest possible phase in the modern era. Following this, the Turkish side took a step back, making an official apology and expressing a desire to resolve the situation. A number of official contacts at the highest level that announced that the disagreements of the parties had been overcome, seemed to pave the way for relations to reach a new level. But, as practice has shown, this did not happen [14, 45].
In case of stabilization of the situation in Syria, conducting intra-Syrian ceasefire negotiations with the active participation of Russia and the United States; 
It can be stated that until recently, Russian-Turkish relations were on the rise, possessing significant potential for regional partnership. However, the situation has changed dramatically, and to date, the parties still have not been able to return to the pre-crisis state of relations.

Turkey is not the only country in the region, relations with which remain difficult. Tensions are also present in RussianIranian interaction, which in many respects is characterized by the lack of trust. On the one hand, Russia supports Iran's position on the United States, and on the other, shares the position of the West, which seeks to take control of Iran's nuclear program. It is significant that in the UN Security Council Russia voted to impose sanctions on Iran. In addition, there was a precedent when, due to the insistent position of Israel, Moscow unilaterally broke off the already paid contract for the delivery of S-300 air defense systems to Iran. But at the same time, when it comes to strategic projects and issues, Moscow and Tehran find a common ground reaching a constructive dialogue. In particular, Russia does not consider Hezbollah and Hamas as terrorist organizations, and within the framework of the Syrian campaign, the interests of Moscow and Tehran also mainly coincide.

As for Saudi Arabia, bilateral relations cannot be called cloudless. Historically, during the Cold War, diplomatic relations were not even established between the parties. However, it should be noted that today, while maintaining differences, primarily on the Syrian issue, Moscow and Riyadh demonstrate an unprecedentedly high level of bilateral contacts both at the level of pragmatic and symbolic politics. In particular, the manifestations of symbolic politics include attributing the title of Honorary Doctor of the MGIMO University to the King Salman of Saudi Arabia [15].

Speaking about the interaction between Russia and Israel in the region, it should be noted that, first of all, the Russianspeaking population makes up about a fifth of the country's population [16]. In addition, state anti-Semitism, which took place in the Soviet era, is a thing of the past. Of course, there remains a number of disagreements between the parties on some issues on the international agenda, but (what is important) Moscow and Tel Aviv proceed from the principle of pragmatism in world politics, considering Islamist terrorism a serious international threat

We should not forget that large Russian corporations, which form an important part of the political system of Russia, also have their interests in the Middle East region. Rosatom has a positive experience of cooperation with Iran on the construction of a nuclear power plant in Bushehr - the corporation is actively working on the development of bilateral cooperation in this direction. In addition, Rosatom has projects in Jordan and Turkey. Likewise, Lukoil is active in Iraq, and Gazprom is a key supplier of gas to Turkey. Along with this, Iran and Qatar are actively cooperating with Russia, forming the basis of the Forum of Gas Exporting Countries. Represented by the large corporations, Russia is pursuing national interests in the region to promote its own status as the largest energy power. This is possible, first of all, due to the intensification of cooperation with OPEC members (in particular, Saudi Arabia).
Specifically, we can look upon the important political incident that occurred after Trump's visit to Riyadh, when he accused Iran of "supporting global terrorism" and designated it as the "main enemy" in the region and Saudi Arabia accused Qatar of fueling "numerous terrorist and sectarian groups "(for example, "Muslim Brotherhood"), which pursue the goal of destabilizing the region, and in cooperation with Iran.

As a result, Saudi Arabia, the UAE, Bahrain and Egypt broke off diplomatic relations with Doha and ceased all communication with Qatar, accusing it of supporting terrorism and interfering in their internal affairs. Later, the Maldives, Mauritius, and Mauritania also declared a break in diplomatic relations. Jordan and Djibouti have lowered their diplomatic missions in Qatar. Senegal, Niger and Chad announced the recall of ambassadors. As a result, only two states that are members of the Gulf Cooperation Council, Kuwait and the Sultanate of Oman, did not join the blockade of Qatar. Qatar rejected all charges and stated that it would not take retaliatory measures.

Many experts note that the cause of the diplomatic crisis was the close relationship between Qatar and Iran, which are jointly engaged in the development of the world's largest gas field South Pars / North Dome.

A number of conditions were put forward to lift the economic blockade of Qatar - in particular, the closure of the Turkish military base in the country, the reduction in the level of diplomatic and military cooperation with Iran, and the closure of the satellite network of the international television company Al Jazeera. Qatar refused to comply with the ultimatum, finding the requirements unacceptable.

Analyzing the current political processes in the Middle East, it can be assumed that tensions are building up [17]. Qatar has successfully withstood the blockade, but any international contacts and allies are extremely important to it.

From the very first days of the crisis, the Iranian leadership unconditionally expressed support for Doha, organized the transfer of a certain amount of food - and by mutual agreement with the Qatari side, Tehran's practical participation in the crisis ended there. Which, of course, was a very wise move by both the Iranians and Qataris.

The active participation of Tehran would lead not only to the rallying of the anti-Qatar coalition, but also to the accession of new members to it. However, this would not arouse understanding either in Qatar itself or in the Sunni East as a whole. Moreover, Qatar had a powerful trump card guarantees, including the military, of Turkey. As a result, the anti-Qatar coalition collapsed, causing serious damage to the prestige of Riyadh.

Separately, it is worth examining cooperation with Turkey, which is trying to play an active role in the region and intends to use the crisis around Qatar to expand its influence and return to the zone of political influence in the Persian Gulf, and is ready to provide political and even military protection to its allies [18]. Turkish leader R.T.Erdogan rather stiffly reacted to the intent of the Arab states to close the Turkish military base in Qatar. 
Turkey, along with Russia, is actively establishing cooperation with Iran on a number of strategic issues: in Syria, and Iraq, and in the Kurdish issue, their interests are intertwined; it is logical to assume that a very active and practical interaction has already been established between Ankara and Tehran. Both countries are well aware and understand each other's interests and intentions and are doing everything possible to avoid clashes and conflicts. The political situation is quite illustrative when Turkey sends its contingent to Qatar and Iran is ready to send it a thousand tons of fruits and vegetables daily.

It is also worth taking into account the Russia-Turkey-Iran alliance in the Syrian direction drawn up by Astana documents, which provides for the creation and strengthening of de-escalation zones in Syria. If we keep in mind two coalitions, Qatar - Iran - Turkey and Russia - Turkey Iran, then the United States can logically play the "Turkish card" in order to further rock the situation in the Middle East [19]. But provided that they refuse to support the Syrian Kurds, which Ankara insists. In turn, Turkey provokes the United States, declaring its readiness to purchase S-400 antiaircraft missile systems from Moscow, although they are a member of the NATO bloc and have the second largest army.

The Pentagon expresses concern about the incompatibility of NATO defense systems and Russian anti-aircraft missile systems, but it does not persistently do it and actively does not prevent this. Perhaps the fact is that Ankara's attempt to play a provocative card with S-400 purchases does not look like a strong move, since for example Greece, which is also a member of NATO, uses Russian air defense systems. The mentioned fact has not yet led to any significant geopolitical crises and in order for Turkey to go all-out in relations with the North Atlantic Alliance and the West, events of force majeure for it should occur in the region that directly affect its national security.

The thesis published in the Turkish newspaper Milli Gazete seems to be important: "Turkey has become aware of the factor of Russia's military presence in the Middle East, not only from the point of view of the future regimes of Syria and Iran", but also of the "the possibility of maintaining a balance of power in regional politics". According to the article, "Turkey, which will lose Russia and Iran as allies, will lose the ongoing game, which can be said vise-versa". And another quote: "Soon, the events that are developing in Syria will occure in Iraq, the Persian Gulf, Afghanistan, Central and South Asia. And the West will have a hard time" [20].

Nevertheless, while Ankara maintains close, primarily economic ties with Doha, Turkey is practically unable to play a mediating role in establishing relations between the Arab states.

Most likely, Ankara will continue to strengthen relations with Moscow and Tehran, leaning towards new privileges and preferences, while at the same time listening to the position of the European countries and taking into account the US reaction $[21,75]$.

\section{DISCUSSION}

So the following conclusions can be drawn. Practice shows that in the Middle East region Russia does not have obvious strategic allies that would support the Moscow line outside the current political context (unlike, for example, the United States, which traditionally support Israel).

Today, one can talk about the following priorities of Russia in the region: engaging the United States for a joint settlement of the Syrian crisis peacefully, expanding ties with Iran within the frameworks of the nuclear deal, maintaining friendly relations with Syrian and Iraqi Kurds [22, 127], development of pragmatic relations with Saudi Arabia, for which interaction with Moscow is part of the diversification of its foreign policy, as well as coordination of foreign policy positions with Israel.

Russia's goal is to earn a reputation among the countries of the region as a pragmatic, strong, non-ideological and reliable political force, which, being in the conditions of the modern polycentric world, is able to use both diplomatic methods and, if necessary, resort to force.

Realizing its interests, Moscow operates in the region rather flexibly, giving priority to its own strategic goals in the international arena [23, 138]. Recently, it was possible to observe a number of Russian actions based on foreign policy balancing, in particular, the cessation of arms supplies to Iran already mentioned above, as well as the limitation of arms exports to Syria in order to maintain relations with Israel. In a similar vein, Russia acts by balancing between Riyadh and Tehran.

As for the Syrian campaign, it is premature to draw unambiguous conclusions due to its incompleteness. Nevertheless, a number of hypotheses can be made right now.

The operation in Syria is a kind of demonstrative gesture of Moscow, aimed at proving its own ambitions on the world political stage. However, at the same time, the interests of Moscow are broader than exclusively Syria, which, none the less, can become the geopolitical stronghold of Russia in the Middle East. By initiating a military campaign, Moscow voiced its own claims to return the status of a key world power. In addition, a number of large Russian corporations hope that demonstrated during the campaign samples of Russian weapons and technologies with their tactical and technical advantages will enhance the prestige of Russian military and technical export products, allowing them to conclude a number of profitable contracts.

As for Turkey, of course, with the thesis declared by the parties that the differences have been resolved, Moscow and Ankara have not reached the previous level of relations, linking each other with a list of economic sanctions. Of course, the return of Russia to the region as a strong player with a good reputation and powerful potential does not meet Ankara's interests, therefore, in all likelihood, a breakthrough in relations will not be expected in the near future, while the scenario with subsequent accidents between the parties and their further settlement seems likely. 
https://www.gazeta.ru/army/2016/10/04/10229405.shtml November 27th, 2019).

\section{REFERENCES}

[1] E. Bazhanov and N. Bazhanova, "Where the Humanity is Heading to?", in World and Politics, 2009, vol. 6 (33), pp. 13-29.

[2] A. Bogaturov, "Three Generations of Foreign Policy Doctrine of Russia", in International Processes, 2007, vol. 1 (13), January-April, pp. 54-69.

[3] E. Bazhanov, "Evolution of the Russian foreign policy (1991-1999)", Moscow: Science Book, 1999, 30 p.

[4] T. Zamakhina, "Putin Told about Russia Role in World in Article to La Stampa", in RG News Agency, November 27th, 2016 [Electronic resource]. Available at: https://rg.ru/2016/11/27/vladimir-putinrasskazal-o-roli-rossii-v-mire-v-state-v-la-stampa.html (Accessed: 30 November 2019).

[5] V. Vinokurov, "Modern Diplomatic Practices: Diplomacy of Power and/or The Power of Diplomacy", in Diplomatic Service, 2015, vol. 2, pp. 14-20.

[6] T. Zamakhina, "Putin Told about Russia Role in World in Article to La Stampa", in RG News Agency, 27 November 2016 [Electronic resource]. Available at: https://rg.ru/2016/11/27/vladimir-putinrasskazal-o-roli-rossii-v-mire-v-state-v-la-stampa.html (Accessed: 30 November 2019).

[7] D. Trenin, "Russia in the Middle East: Moscow's Objectives, Priorities, and Policy Drivers", in Carnegie Moscow Center [Electronic resource]. Available at: https://carnegie.ru/2016/04/05/russia-in-middle-eastmoscow-s-objectives-priorities-and-policy-drivers-pub-63244 (Accessed: 27 November 2019).

[8] K. Kausch, "Competitive Multipolarity in the Middle East", in IAI Working Papers, 2014, no. 14/10 [Electronic resource]. Available at: http://www.iai.it/en/node/2358 (Accessed: 30 November 2019).

[9] J. Hannah, "Russia's Middle East Offensive", Foreign Policy online, 13 September 2016 [Electronic resource]. Available at: http://foreignpolicy.com/2016/09/13/russias-middle-east-offensive (Accessed: 30 November 2019).

[10] M. Voskresenskiy, "Do not Stop Military from Doing their Job: Satanovsky about the Akerbat Operation in Syria", in RIAFAN Federal News Agency, 22 August 2017 [Electronic resource]. Available at: https://riafan.ru/927561-ne-meshaite-voennym-delat-svoe-delosatanovskii-ob-akerbatskoi-operacii-v-sirii (Accessed 27 November 2019).

[11] M. Khodarenok, "In Syria 'the Afghan Scenario' is Played", in Gazeta News Agency, 4 October 2016 [Electronic resource]. Available at:
[12] "A Year in Syria: How Much Did Military Operation Cost Russia", in RBC News Agency, 30 September 2016 [Electronic resource]. Available at: https://www.rbc.ru/politics/30/09/2016/57ebb7199a7947db5bb2b309 (Accessed: 27 November 2019).

[13] A. Okyay and J. Zaragoza-Cristiani, "The Leverage of the Gatekeeper: Power and Interdependence in the Migration Nexus Between the EU and Turkey", The International Spectator, 2016, vol. 51, no. 4, pp. 51-66.

[14] R. Shangaraev, "'Mutualism' or Pecularities of Turkey Foreign Policy towards Russia", in Security Issues, 2017, vol. 1, pp. 45-54.

[15] "King of Saudi Arabia - Honorary Doctor of MGIMO University", in MGIMO Official Website, 7 October 2017 [Electronic resource]. Available at: https://mgimo.ru/about/news/main/korol-saudovskoyaravii-pochetnyy-doktor-mgimo/ (Accessed: 29 November 2019).

[16] S. Attias, "Russian Soft Power in the Middle East", The Begin-Sadat Center for Strategic Studies, 26 July 2019 [Electronic resource]. Available at: https://besacenter.org/perspectives-papers/russian-softpower-middle-east/ (Accessed: 27 November 2019).

[17] K. Haggag, "A Regional Order Contested", The Cairo review of Global Affairs, 2019, no. 33 [Electronic resource]. Available at: https://www.thecairoreview.com/essays/a-regional-order-contested/ (Accessed: 30 November 2019).

[18] S. Charap, "Is Russia an outside power in the Gulf?", Survival, 57 (1), pp. 153-170 [Electronic resource]. Available at: https://doi.org/10.1080/00396338.2015.1008309 (Accessed: 29 November 2019).

[19] J. Sladden and et al., "Russian Strategy in the Middle East", Rand Perspectives, 2017, no. 236 [Electronic resource]. Available at: https://www.rand.org/pubs/perspectives/PE236.html (Accessed: 30 November 2019).

[20] "MilliGazete", Official Website [Electronic resource]. Available at: https://www.milligazete.com.tr/ (Accessed: 29 November 2019).

[21] R. Shangaraev, "'Democratic Islamism' of AK Parti and its Influence on Turkey Foreign Policy", in Diplomatic Service, 2017, vol. 6, pp. 75-80.

[22] R. Shangaraev, "Kurds Issue in Turkey Foreign Policy on Middle East", in Herald of Diplomatic Academy of MFA of Russia, Russia and the World, 2018, vol. 2 (16), pp. 127-135.

[23] T. Graham, "Let Russia be Russia", Foreign Affairs, 2019, vol. 98, no. 6, pp. 134-147. 